\title{
PEMBERDAYAAN SANTRI MELALUI PEMBELAJARAN ENJOYABLE LEARNING DALAM MEMBENTUK GENERASI SEIMBANG DAN SPIRITUALITAS INTELEKTUALITAS DI PONDOK PESANTREN
}

\author{
Nur Hasan', Gali Setyowidodo², Muhammad Syahrul Wafa², Muchammad Irfan ${ }^{3}$, \\ Subhan Riadi2, Khirzah Annafisah"1, M Ilham Rio Alfanny33, Irma Aprilia1, Tuba Gus \\ Faizin', Novidatur Rizkiyah', Ahmad Nailu Minhajjil Qowim \\ ${ }^{1}$ Fakultas Agama Islam, Universitas Islam Malang \\ ${ }^{2}$ Fakultas Ekonomi dan Bisnis, Universitas Islam Malang \\ ${ }^{3}$ Fakultas Teknik, Universitas Islam Malang \\ ${ }^{4}$ Fakultas Matematika dan Ilmu Pengetahuan Alam, Universitas Islam Malang \\ Korespondensi email: nurhasan070778@gmail.com
}

\begin{abstract}
ABSTRAK
Era revolusi 4.0 menjadi era yang digadang-gadangkan menjadi era keberhasilan pada sejarah manusia. Era tersebut menuntut manusia harus mampu bersikap seimbang dalam menyikapi perkembangan ilmu pengetahuan, kemampuan santri dalam spiritualitas dan inteklektualitas merupakan suatu keharusan yang wajib miliki oleh santri milenial, apabila keduanya seimbang maka santri tidak akan teromabang ambing oleh perubahan zaman yang begitu cepat. Pembelajaran Enjoyable learning merupakan langkah awal untuk merubah mindset santri dalam memahami agama dari mindset tradisional menjadi mindset intelektual religius yang mampu menghadapi segala kemungkinan perubahan zaman. Dalam pengabdian masyarakat ini pengabdi menggunakan metode Participatory Action and Learning System (PALS). Metode ini merupakan salah satu metode pemberdayaan sasaran yang merupakan bagian dari PLA (Participatory Learning and Action). Dengan metode ini, maka masyarakat sasaran (pesantren) diperlakukan sebagai subjek sekaligus objek dalam kegiatan Pengabdian kepada masyarakat, Sasaran pengabdian ini adalah pondok pesantren Miftahul Ulum Annur yang berada di Desa Majangtengah Kecamatan dampit Kabupaten Malang. Hasilnya adalah mengadakan sarasehan pada santriwan dan santriwati tentang model pembelajaran yang menyenangkan (Enjoyable Learning) oleh pemateri secara khusus dengan menyajikan materi-materi yang mengandung unsur motivasi agar santri siap menghadapi era revolusi 4.0 yang mengharuskan terpondasikan jiwa spiritual yang kuat dan seimbang dengan in telektual yang sangat mumpuni.
\end{abstract}

Kata Kunci: enjoyable learning; spiritualitas; intelektualitas.

\section{PENDAHULUAN}

Keberadaan pondok pesantren bukanlah suatu hal yang baru. Citra pondok pesantren juga dikenal dengan sangat baik. Hal terebut terbukti dari anggapan bahwa pesantren adalah lembaga pendidikan yang mampu membentuk akhlakul karimah dan banyak menghasilkan kader ulama dan da'i (Krisdiyanto et al., 2019).

Kesuma (2017) menyatakan bahwa seiring berkembangnya zaman, pondok pesantren dituntut untuk melakukan pembaharuan baik dalam proses pembelajaran 
maupun berinteraksi dengan dunia luar. Dalam proses pembelajaran misalnya, pesantren perlu juga menggunakan model-model pembelajaran yang sifatnya masa kini selain model pembelajaran yang sifatnya sorogan, begitu juga pesantren harus sudah mulai terbuka dan mampu bekerjasama dengan instansi-nstansi di luar pesantren, sehingga masyarakat semakin mendapat kesempatan luas untuk berhubungan pesantren untuk mendapat ilmu pengetahuan sebanyak-banyaknya.

Sesuai dengan fakta yang ditemukan di lapangan. Kini, pondok pesantren juga sudah banyak mengembangkan sistem pendidikan dan pengajarannya agar sesuai dengan kebutuhan masyarakat. Sehingga para alumni atau lulusannya mampu seperti yang diharapakan masyarakat untuk siap bersaing dengan dunia luar (Sidiq, 2013) (Setyawan, 2016).

Adapun fakta tersebut ditemukan di Pondok Pesantren Miftahul Ulum Annur Dusun Kidul Kali Desa Majang Tengah Kecamatan Dampit Kabupaten Malang. Pondok Pesantren tersebut tergolong sebagai pondok pesantren yang berkembang. Hal tersebut dapat dilihat dari sistem pendidikan di dalamnya yang telah diadakannya satuan pendidikan formal. Antara lain RA Sultan Agung, MI, MTs, dan MA Miftahul Ulum Annur.

Perkembangan dari Pondok Pesantren Miftahul Ulum Annur Dusun Kidul Kali Desa Majang Tengah Kecamatan Dampit Kabupaten Malang tak lepas dari permasalahan yang ditemukan oleh pengabdi. Pengabdi menemukan masalah-masalah yang dirasa harus segera ditangani agar tidak menjadi masalah yang besar dikemudian hari. Adapun permasalahan yang mendominasi tersebut antara lain, kurangnya motivasi dari peserta didik untuk pada kegiatan pembelajaran berlangsung dan pengunaan metode guru dalam penyampaian materi yang masih menggunakan ceramah secara keseluruhan. Walaupun masih ada program dari sekolah yaitu istighotsah berjama'ah untuk seluruh warga lembaga pendidikan formal Miftahul Ulum Annur meski sudah cukup tertib pada kelanjutan program tersebut. Yaitu Sholat Dhuha, dimana kegiatan tersebut kurang begitu continue atau istiqomah (Kurniasih et al., 2019).

Melalui pemaparan di atas, dapat di katakan bahwa Pondok Pesantren Sebagai Agent Of Change, oleh sebab itu perlu dibuat Sistem Pembelajaran Pesantren yang menarik dan tidak membosankan di era Industri 4.0 (Idrus, 2016) (Alfi, 2020). Santri perlu di ajak terlibat langsung dalam diskusi, membaca, bermain yang arahnya pada materi pembelajaran, sehingga santri akan merasa lebih tertarik untuk menyampaikan ide-idenya selamanya kegiatan belajar berlangsung (Fuadah \& Sanusi, 2017). Berdasarkan pengamatan di lapangan Pondok Pesantren Miftahul Ulum Annur merupakan pesantren dari banyak pesantren yang turut berjuang dalam pendidikan di Indonesia. Meski berbasis agama berupa sistem pendidikan pesantren, juga turut berkembang melalui lembaga formal, sebagai penunjang pendidikan para santrinya yang saat ini tengah hidup di era Industri 4.0 (Ulia et al., 2019).

Sehingga Pondok Pesantren Miftahul Ulum Annur memiliki memiliki potensi yang mumpuni dalam hal pendidikan yang cukup memadai dengan basis syiar islam yang moderat. Hal tersebut dapat dilihat dari detail kegiatan yang senantiasa istiqomah menjadi amaliyah santri dan sekaligus boleh diikuti warga sekitar pesantren. Adapun kegiatan tersebut antara lain: kegiatan belajar pembelajaran sekolah formal, madrasah diniyah, dan aktivitas di masjid seperti: sholat berjama'ah, istighotsah, maulid diba', wirid, dan lain sebagainya. 


\section{METODE}

Dalam pengabdian masyarakat ini pengabdi menggunakan metode Participatory Action and Learning System (PALS). Metode ini merupakan salah satu metode pemberdayaan sasaran yang merupakan bagian dari PLA (Participatory Learning and Action). Dengan metode ini, maka masyarakat sasaran (pesantren) diperlakukan sebagai subjek sekaligus objek dalam kegiatan Pengabdian kepada masyarakat, Sasaran pengabdian ini adalah pondok pesantren Miftahul Ulum Annur yang berada di Desa Majangtengah Kecamatan dampit Kabupaten Malang. Dalam metode PALS, peningkatan kapasitas masyarakat dilakukan dengan berbagai model, diantaranya pendidikan, sarasehan, penyuluhan, serta pembinaan dan pendampingan. Dalam hal ini, pengabdi mengumpulkan data dan melaporkan sebuah deskripsi terkait pelaksanaan sebuah metode pembelajaran yang menyenangkan (enjoyable learning) yang ter cover dalam kegiatan sarasehan untuk mempersiapkan dan mewujudkan generasi masa depan dari Pondok Pesantren Miftahul Ulum Annur Desa Majangtengah Kecamatan Dampit dengan kemampuan spiritualitas-intelektualitas yang seimbang.

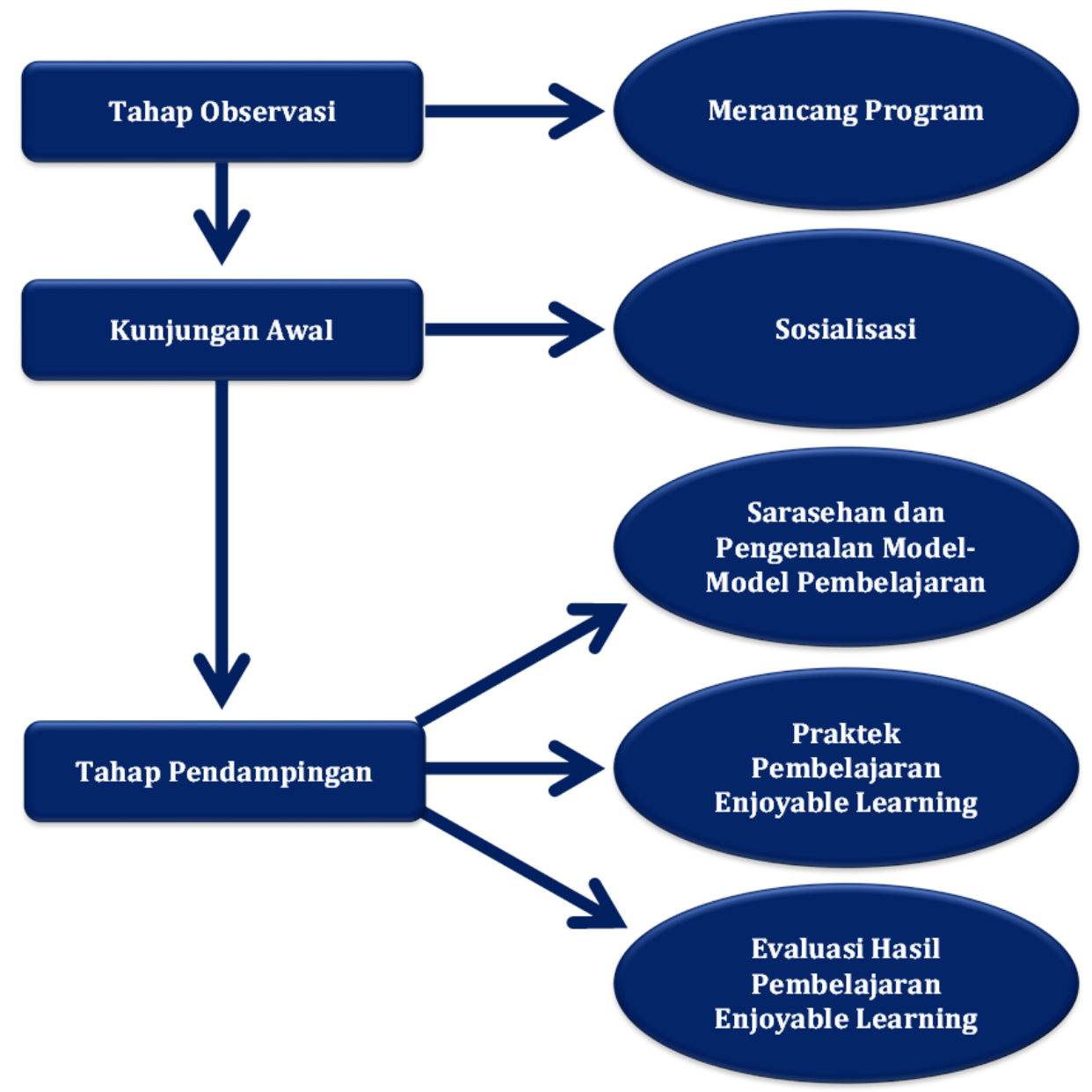

Gambar 1. Bagan tahapan-tahapan pelaksanaan program (sumber : Dibuat oleh tim Pengabdian Kepada Masyarakat)

\section{HASIL DAN PEMBAHASAN}

Pondok Pesantren Miftahul Ulum Annur Desa Majangtengah salah satu objek dalam pengabdian kepada masyarakat pada pendidikan pesantren. Terletak di Desa Majangtengah kecaatan Dampit Kabupaten Malang. Juga merupakan pesantren yang dalam 
tahap berkembang dalam rangka mendidik santri-santrinya agar menjadi generasi penerus yang seimbang spiritualitas dan intelektualitasnya.

Kegiatan sarasehan yang bertemakan "Menyiapkan Generasi Masa Depan dengan Kemampuan Spiritualitas Intelektualitas yang Seimbang" bersama pemateri dari Universitas Islam Malang dosen Fakultas Agama Islam yang juga seorang alumni santriwati Pondok Pesantren Genggong yaitu Qurroti A'yun, M.PdI dengan sasaran santriwan dan santriwati podok pesantren Miftahul Ulum Annur.

1. Pemateri memberikan gambaran bahwasanya dalam melakukan segala hal diawali dari hal yang terkecil kemudian melalui beberapa fase yang dilalui, sehingga tujuan yang di harapkan tercapai.

2. Memberikan motivasi bahwa anak pesantren bisa menyeimbangkan antara ilmu agama dan pengetahuan umum, mendorong para santri agar lebih semangat untuk meraih cita-cita dan membuktikan bahwa anak pesantren bisa menjadi tauladan yang baik bagi masyarakat sekitar, dan memberikan penegasan agar anak pesantren tidak boleh menyerah karena janji Allah yang tercantum di dalam QS. Al Insyirah ayat 6 yang artinya "Sesungguhnya bersama kesulitan pasti ada kemudahan". Menjelaskan kandungan surat Az-Zumar ayat 9 yang menjelaskan tentang apakah Keistimewaan dan keutamaan orang yang berilmu, orang memliki ilmu mempunyai keistimewaan dan keutamaan tersendiri dalam Islam. Dan Menjelaskan tentang kandungan surat Al Mujadalah ayat 11 yang artinya "bahwa Allah SWT akan mengangkat derajat orangorang yang beriman dan berilmu beberapa derajat'.

Pengembangan metode pembelajaran berupa enjoyable learning berupa sarasehan yang telah dirancang dengan matang, mendapat respon yang sangat positif dari sasaran yaitu santri Pondok Pesantren Miftahul Ulum Annur. Selain itu juga mendapat apresiasi dari pihak pengasuh dan pengurus Pondok Pesantren Miftahul Ulum Annur yang turut berpartisipasi.

Pada kali ini sarasehan di Pondok Pesantren Miftahul Ulum Annur dirancang oleh pemateri secara khusus dengan menyajikan materi-materi yang mengandung unsur motivasi agar santri siap menghadapi era revolusi 4.0 yang mengharuskan terpondasikan jiwa spiritual yang kuat dan seimbang dengan in telektual yang sangat mumpuni. Sarasehan yang diberikan meski dengan metode ceramah juga diselingi kuis berupa problem solving yang mengasyikkan berupa slide sehingga sasaran bisa tertarik sehingga terangsang untuk merespon keaktifan mereka.

Melaui enjoyable learning "sarasehan" diharapkan mampu menstimulus sasaran agar lebih bersemangat dalam belajar karena psikologi sasaran dalam keadaan yang prima. Selain itu juga menjadi inspirasi penghembang lainnya ataupun pendidik lainnya. Karena dalam prakteknya melalui rincian di atas, enjoyable learning "sarasehan" dirasa lebih efektif dan mampu merangsang keaktifan anak.

\section{KESIMPULAN}

Pengembangan metode pembelajaran berupa enjoyable learning berupa sarasehan yang telah dirancang dengan matang, mendapat respon yang sangat positif dari sasaran yaitu santri Pondok Pesantren Miftahul Ulum Annur. Selain itu juga mendapat apresiasi dari pihak pengasuh dan pengurus Pondok Pesantren Miftahul Ulum Annur yang turut berpartisipasi. Melaui enjoyable learning "sarasehan" diharapkan mampu menstimulus sasaran agar lebih bersemangat dalam belajar karena psikologi sasaran dalam keadaan yang prima. Selain itu juga menjadi inspirasi penghembang lainnya ataupun pendidik lainnya. Karena dalam prakteknya melalui rincian di atas, enjoyable learning "sarasehan" dirasa lebih efektif dan mampu merangsang keaktifan anak. 


\section{DAFTAR RUJUKAN}

Alfi, I. (2020). Strategi Pesantren dalam Pemberdayaan Masyarakat pada Era Generasi 4.0. MATAN: Journal of Islam and Muslim Society, 2(1), 26-39. https://doi.org/https://doi.org/10.20884/1.matan.2020.2.1.2244

Fuadah, F. S., \& Sanusi, H. P. (2017). Manajemen Pembelajaran di Pondok Pesantren. Jurnal ISEMA, 2(2), 40-58. https://doi.org/10.1017/CB09781107415324.004

Idrus, M. A. J. al. (2016). Menakar Peran Pesantren Dalam Mengembangkan Pendidikan Tinggi Menghadapi Era Globalisasi. Jurnal Tatsqif (Jurnal Pemikiran Dan Penelitian Pendidikan), 12(2), 238-257. https://doi.org/10.20414/jtq.v14i2.31

Kesuma, G. C. (2017). Refleksi Model Pendidikan Pesantren dan Tantangannya Masa Kini. Tadris: Jurnal Keguruan Dan Ilmu Tarbiyah, 2(1), 67. https://doi.org/10.24042/tadris.v2i1.1740

Krisdiyanto, G., Muflikha, M., Sahara, E. E., \& Mahfud, C. (2019). Sistem Pendidikan Pesantren dan Tantangan Modernitas. Tarbawi: Jurnal Ilmu Pendidikan, 15(1), $11-$ 21. https://doi.org/10.32939/tarbawi.v15i1.337

Kurniasih, Rahmati, N. A., Umamah, A., \& Widowati, D. R. (2019). English Conversation Class (ECC) Untuk Menciptakan English Environment Di SMA Islam Nusantara (SMAINUS). Jurnal Inovasi Hasil Pengabdian Masyarakat (JIPEMAS), 2(2), 161. https://doi.org/10.33474/jipemas.v2i2.2571

Setyawan, C. E. (2016). Menggagas Model Pengembangan Standarisasi Sistem Pendidikan Pesantren. At Ta'Dib, 11(2), 227-240. https://doi.org/10.21111/at-tadib.v11i2.777

Sidiq, U. (2013). Pengembangan Standarisasi Pondok Pesantren. Nadwa: Jurnal Pendidikan Islam (Islamic Education Journal), $\quad 7(1), \quad 71-88$. https://doi.org/10.21580/nw.2013.7.1.544

Ulia, N., Ismiyanti, Y., \& Setiana, L. N. (2019). Meningkatkan Literasi Melalui Bahan Ajar Tematik Saintifik Berbasis Kearifan Lokal. Jurnal Inovasi Hasil Pengabdian Masyarakat (JIPEMAS), 2(2), 150-160. https://doi.org/10.33474/jipemas.v2i2.3402 